Female runners

\section{Women will do it in the long run}

\section{R Beneke, R M Leithäuser, M Doppelmayr}

\section{In long distance races female runners can beat male runners}

W ill female athletes ever outpace male athletes in running events? Time and again this question has caused the most ambitious debates with considerable recognition in the "lay"1 and sports science society..$^{2-5}$ Although serious consideration does not indicate the slightest chance of a woman being the fastest human on the planet at distances of 100-200 m, there are factors that may favour women over longer distances.

It is not only the rapid improvement in female running, especially over the marathon distance, between 1963 and 1984 that supports the idea that women may have a chance of outpacing men. Further support comes from findings such as differences in the ability to run aerobically at a higher percentage of maximal oxygen uptake, ${ }^{6}$ the use of ingested and stored glycogen, ${ }^{6}$ lipid metabolism, ${ }^{7}$ and possibly the acute response of growth hormones, ${ }^{8}$ in the balance between gene transcription, translation, protein breakdown, ${ }^{9}$ resistance to oxidative stress, ${ }^{10}$ and also pain perception. ${ }^{11}$ However, men have always been faster over Olympic distances, and further analyses support the idea that the sex difference of about 10\% in races up to $200 \mathrm{~km}$ has more or less plateaued..$^{12}$
Regardless of whether such analyses provide meaningful clues and whether female athletes will be able to close on male athletes in races up to $200 \mathrm{~km}$, consistent male superiority is already a matter of history in possibly the most challenging ultra-race, the "Badwater Ultramarathon", a $216 \mathrm{~km}$ race at temperatures of up to $55^{\circ} \mathrm{C}$. Men dominated during the 1980s and 1990s, but, in spite of potential female handicaps in an extremely hot environment, ${ }^{13}$ in 2002 and 2003, a female ultra-runner outpaced the fastest man by about 4.5 and 0.5 hours respectively. Furthermore, since 2002, up to three women have been in the first five finishers, even though there were more male than female participants. Whether $216 \mathrm{~km}$ is long enough for women to consistently outpace men may be seen in the near future.

Br J Sports Med 2005;39:410.

doi: 10.1136/bjsm.2004.017574

\section{Authors' affiliations}

R Beneke, R M Leithäuser, Centre for Sports and Exercise Sciences, Department of Biological Sciences, University of Essex, Colchester, UK

M Doppelmayr, University of Salzburg, Salzburg, Austria
Correspondence to: Dr Beneke, Centre of Sports and Exercise Sciences, University of Essex, Colchester CO4 3SQ, UK; rbeneke@ essex.ac.uk

\section{REFERENCES}

1 Tatem AJ, Guerra CA, Atkinson PM, et al. Momentous sprint at the 2156 Olympics? Nature 2004:431:525.

2 Holden C. An everlasting gender gap? Science 2004;305:639-40.

3 Peronnet F, Thibault G. Mathematical analysis of running performance and world running records. $J$ Appl Physiol 1989;67:453-65.

4 Whipp BJ, Ward SA. Will women soon outrun men? Nature 1992;355:25.

5 Maldonado-Martin S, Mujika I, Padilla S. Physiological variables to use in the gender comparison in highly trained runners. J Sports Med Phys Fitness 2004;44:8-14.

6 Riddell MC, Partington SL, Stupka N, et al. Substrate utilization during exercise performed with and without glucose ingestion in female and male endurance trained athletes. Int J Sport Nutr Exerc Metab 2003; 13:407-21.

7 Perreault L, Lavely JM, Kittelson JM, et al. Gender differences in lipoprotein lipase activity after acute exercise. Obes Res 2004;12:241-9.

8 Sartorio A, Agosti F, Marazzi N, et al. Gender-, age-, body composition- and training workloaddependent differences of $\mathrm{GH}$ response to a discipline-specific training session in elite athletes: a study on the field. J Endocrinol Invest 2004;27:121-9.

9 Gonzalez-Cadavid NF, Bhasin S. Role of myostatin in metabolism. Curr Opin Clin Nutr Metab Care 2004;7:451-7.

10 Illan N, Kamanli A, Ozmerdivenli R, et al. Variable effects of exercise intensity on reduced glutathione, thiobarbituric acid reactive substance levels, and glucose concentration. Arch Med Res 2004;35:294-300.

11 Wise EA, Price DD, Myers CD, et al. Gender role expectations of pain: relationship to experimental pain perception. Pain 2002;96:335-42.

12 Coast JR, Blevins JS, Wilson BA. Do gender differences in running performance disappear with distance? Can J Appl Physiol 2004;29:139-45.

13 Cheung SS, McLellan TM, Tenaglia S. The thermophysiology of uncompensable heat stress. Physiological manipulations and individual characteristics. Sports Med 2000;29:329-59. 